\title{
Corrosion and Environmental Effects on Electronic Systems
}

\author{
Ambat, Rajan; Møller, Per; Westermann, Peter Jacob Schwencke
}

Published in:

Meeting Abstracts - Electrochemical Society

Publication date:

2006

Document Version

Publisher's PDF, also known as Version of record

Link back to DTU Orbit

Citation (APA):

Ambat, R., Møller, P., \& Westermann, P. J. S. (2006). Corrosion and Environmental Effects on Electronic Systems. In Meeting Abstracts - Electrochemical Society (pp. Abstract 800). The Electrochemical Society.

\section{General rights}

Copyright and moral rights for the publications made accessible in the public portal are retained by the authors and/or other copyright owners and it is a condition of accessing publications that users recognise and abide by the legal requirements associated with these rights.

- Users may download and print one copy of any publication from the public portal for the purpose of private study or research.

- You may not further distribute the material or use it for any profit-making activity or commercial gain

- You may freely distribute the URL identifying the publication in the public portal

If you believe that this document breaches copyright please contact us providing details, and we will remove access to the work immediately and investigate your claim. 


\section{CORROSION AND ENVIRONMENTAL EFFECTS ON ELECTRONIC SYSTEMS}

\author{
Rajan Ambat, Per Møller, and Peter Westermann \\ Division of Materials Science and Engineering \\ Department of Manufacturing and Management \\ Technical University of Denmark \\ DK 2800 Kgs. Lyngby, Denmark \\ ra@ipl.dtu.dk
}

In recent years, corrosion of electronic systems has been a significant issue due to the development of complex systems and increasing demand for their reliability. The demand for miniaturization, multiplicity of materials used, effect of process residues together with unpredictable user environment has opened up serious corrosion problems. The miniaturization of electronic devices reduces both the size of components and the spacing between them on printed circuit boards (PCBs). Material loss of the order of $10^{-12}$ grams can cause failures like short circuiting or current leakage in such tiny circuits; therefore even a minute environmental impact can have adverse effect on the performance of the electronic systems. Although the cost of corrosion in electronic sector could not be estimated, it has been suggested that a significant part of all electronic system failures are caused by corrosion.

Over the last 10 years, the pattern of electronics usage has been considerably changed due to the increased use of electronically controlled machines, use of more electronics in the transportation sector, and rapid growth in consumer electronics. For all applications, the demand for miniaturization, use of unfavorable (from corrosion point of view) material combinations, process residues, and ever expanding domain of service related contamination has opened up serious corrosion problems. The consumer electronics sector is one area where the user environment is highly unpredictable. One such example is the wide-spread use of cell phones.

Recently the use of cell phone and other portable consumer electronics has increased to gigantic proportions and spread all over the world in different climatic zones. At the same time, the cell phone has become a necessity for many that is brought with them in any activity they practise. The change in user behaviour has heavily affected the cell phone reliability due to environmental factors such as moisture, sweat and corrosive atmospheres. For any particular user the environmental domain at which the phone operated is varied and unpredictable.

This paper focuses on the corrosion investigation of mobile phone dome-key pad system, and reviews some of the factors leading to corrosion in electronic devices. Mobile phone dome-key pad system is the device that connects the phone keys to the printed circuit board (PCB). The material combination for a typical dome-key pad system is Ag/AISI 202 steel for the dome and $\mathrm{Au} / \mathrm{Ni} / \mathrm{Cu}$ for the key pad. Under humid conditions domekey pad system is susceptible to multiple corrosion problems. The corrosion susceptibility of dome (Ag/AISI 202 steel) and key pad system $(\mathrm{Au} / \mathrm{Ni} / \mathrm{Cu})$ is investigated with an aim to understand the corrosion performance of such multi-material combinations in chloride containing environment. Investigation includes microstructural studies, polarization measurements using microelectrochemical technique, salt spray testing, and corrosion morphology analysis. The immersion Au layer on pads showed pores and rolled bonded silver layer on dome had cracks and kinks. The difference in electrochemical behaviour of the metallic layers together with imperfections in the top layer resulted in severe pitting due to galvanic coupling. The results are applicable to a broad spectrum of PCB parts where similar material combinations are employed, especially $\mathrm{Au} / \mathrm{Ni} / \mathrm{Cu}$.

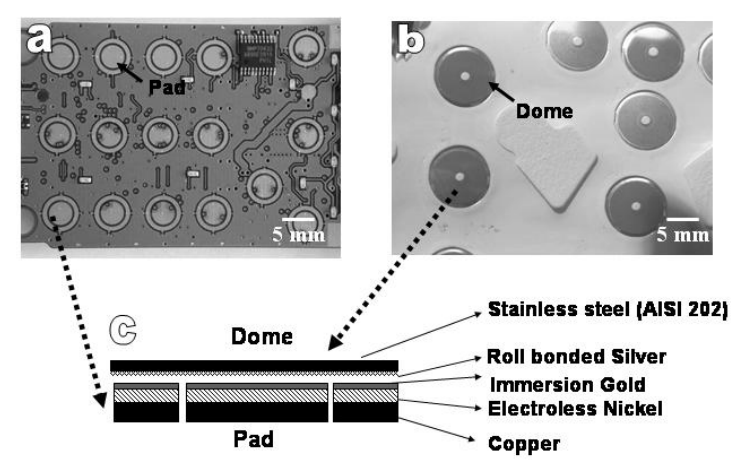

Figure 1. Mobile phone dome-key pad system: (a) pads on PCB, (b) domes, and (c) a schematic of the dome-key pad arrangement in a mobile phone.
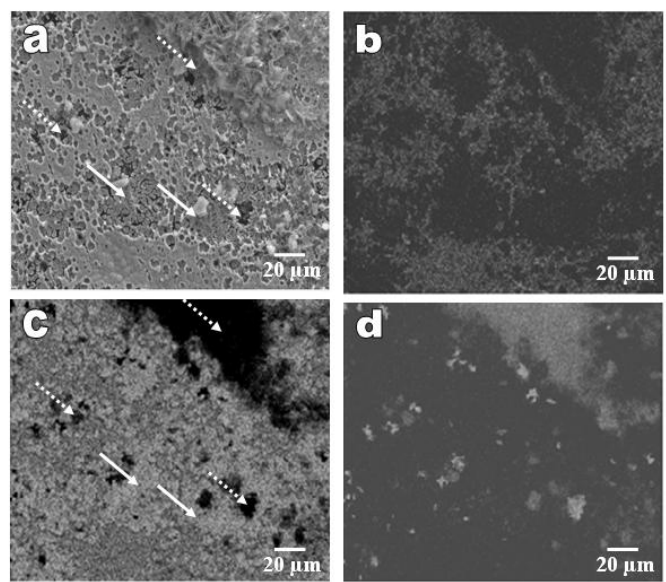

Figure 2. Corrosion surface morphology of a pad after salt spray testing: (a) SEM BE image showing localized corrosion, and (b)-(d) X-ray map for $\mathrm{Au}, \mathrm{Ni}$ and $\mathrm{Cu}$. 